GLASILO

FUTURE

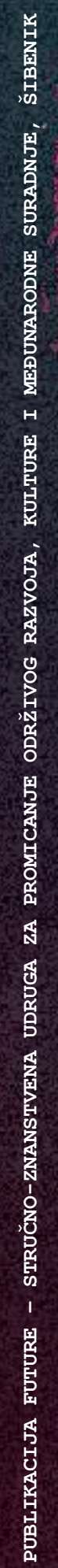

VOLUMEN 1 BROJ 5-6

PROSINAC 2018.

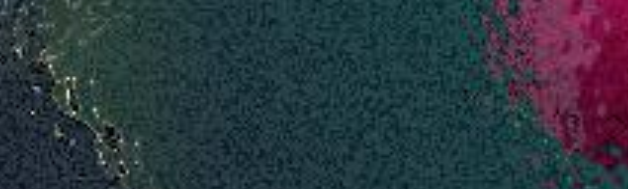

UDK 60

UDK 631

UDK 630

UDK 336

UDK 338
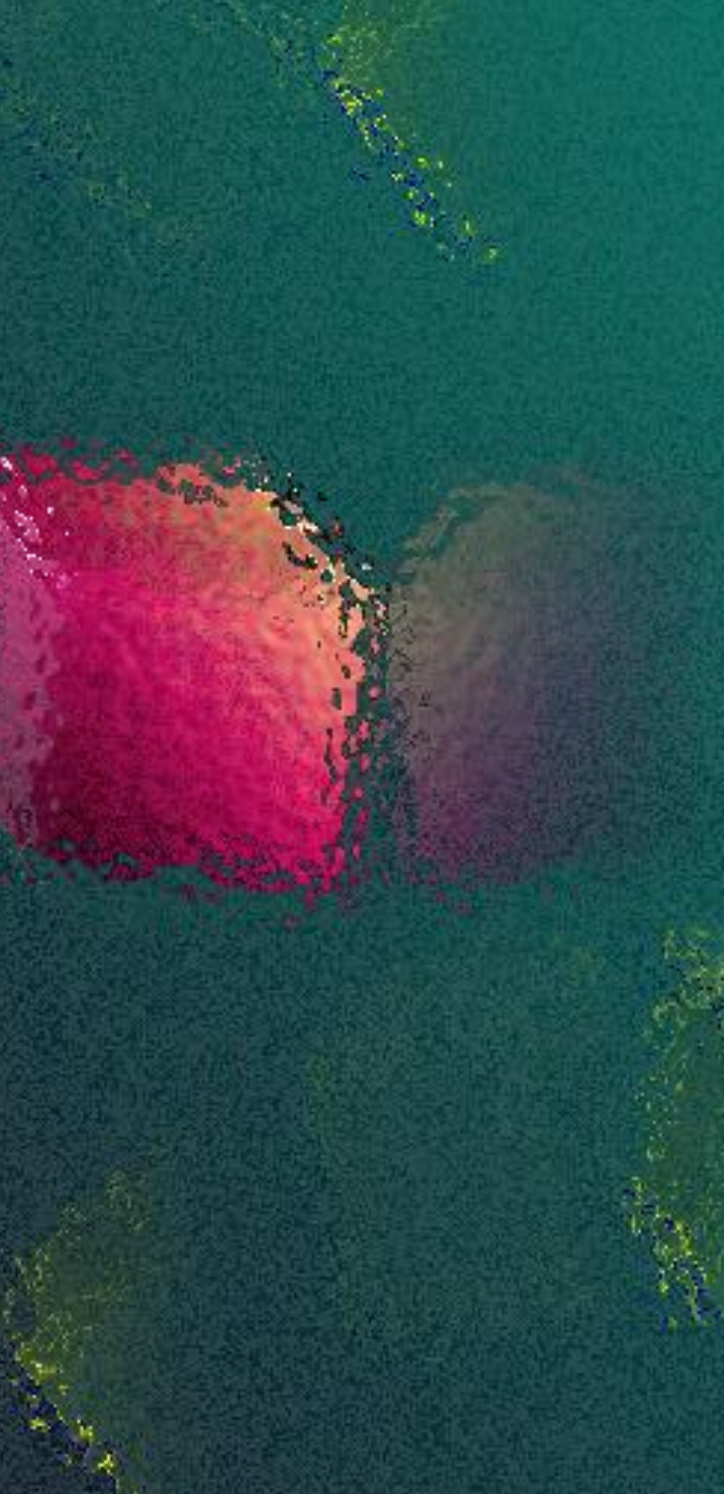


\section{Glasilo Future}

\section{Stručno-znanstveni časopis}

Nakladnik: FUTURA

\section{FUTUR}

Sjedište udruge: Šibenik

\section{Adresa uredništva:}

Bana Josipa Jelačića 13 a, 22000 Šibenik, Hrvatska / Croatia 留 / 圆: +385 (0) 022218133

$\triangle$ : urednistvo@gazette-future.eu / editors@gazette-future.eu (3): www.gazette-future.eu

\section{Uređivački odbor / Editorial Board:}

Doc. dr. sc. Boris Dorbić, v. pred. - glavni i odgovorni urednik / Editor-in-Chief

Emilija Friganović, dipl. ing. preh. teh., v. pred. - zamjenica g. i o. urednika / Deputy Editor-in-Chief

Ančica Sečan Matijaščić, mag. act. soc. - tehnička urednica / Technical Editor

Antonia Dorbić, mag. art. - zamjenica tehničke urednice / Deputy Technical Editor

Prof. dr. sc. Željko Španjol

Mr. sc. Milivoj Blažević

Vesna Štibrić, dipl. ing. preh. teh.

\section{Međunarodno uredništvo / International Editorial Board:}

Prof. dr. sc. Kiril Bahcevandziev - Portugal (Instituto Politécnico de Coimbra)

Prof. dr. sc. Martin Bobinac - Srbija (Šumarski fakultet Beograd)

Doc. dr. sc. Zvezda Bogevska - Makedonija (Fakultet za zemjodelski nauki i hrana Skopje)

Dario Bognolo, mag. ing. - Hrvatska (Veleučilište u Rijeci)

Prof. dr. sc. Agata Cieszewska - Poljska (Szkoła Główna Gospodarstwa Wiejskiego w Warszawie)

Dr. sc. Bogdan Cvjetković, prof. emeritus - Hrvatska (Agronomski fakultet Zagreb)

Prof. dr. sc. Duška Ćurić - Hrvatska (Prehrambeno-biotehnološki fakultet Zagreb)

Doc. dr. sc. Margarita Davitkovska - Makedonija (Fakultet za zemjodelski nauki i hrana Skopje)

Doc. dr. sc. Dubravka Dujmović Purgar - Hrvatska (Agronomski fakultet Zagreb)

Prof. dr. sc. Semina Hadžiabulić - Bosna i Hercegovina (Agromediteranski fakultet Mostar)

Prof. dr. sc. Péter Honfi - Mađarska (Faculty of Horticultural Science Budapest)

Prof. dr. sc. Valeria Ivanova - Bugarska (Fakultet za lozaro-gradinarstvo Plovdiv)

Doc. dr. sc. Orhan Jašić - Bosna i Hercegovina (Filozofski fakultet Tuzla)

Prof. dr. sc. Tajana Krička - Hrvatska (Agronomski fakultet Zagreb)

Prof. dr. sc. Biljana Lazović - Crna Gora (Biotehnički fakultet Podgorica)

Prof. dr. sc. Bosiljka Mustać - Hrvatska (Sveučilište u Zadru)

Hrv. akademik prof. dr. sc. Stanislav Nakić - Bosna i Hercegovina (Sveučilište Hercegovina Mostar)

Sandra Popović, mag. ing. - Srbija (Poljoprivredni fakultet Beograd)

Doc. dr. sc. Bojan Simovski - Makedonija (Šumarski fakultet Skopje)

Prof. dr. sc. Davor Skejić - Hrvatska (Građevinski fakultet Zagreb)

Doc. dr. sc. Milan Stanković - Srbija (Univerzitet u Kragujevcu)

Akademik prof. dr. sc. Refik Šećibović - Bosna i Hercegovina (Visoka škola za turizam i menadžment Konjic)

Prof. dr. sc. Andrej Šušek - Slovenija (Fakulteta za kmetijstvo in biosistemske vede Maribor)

Prof. dr. sc. Elma Temim - Bosna i Hercegovina (Agromediteranski fakultet Mostar)

Doc. dr. sc. Ivana Vitasović Kosić - Hrvatska (Agronomski fakultet Zagreb)

Doc. dr. sc. Ana Vujošević - Srbija (Poljoprivredni fakultet Beograd)

Prof. dr. sc. Vesna Židovec - Hrvatska (Agronomski fakultet Zagreb)

Lektura i grafička priprema: Ančica Sečan Matijaščić, mag. act. soc.

Objavljeno: 31. prosinca 2018. godine.

Časopis izlazi u elektroničkom izdanju dva puta godišnje, krajem lipnja i prosinca, a predviđena su i dva interdisciplinarna specijalna izdanja tijekom godine iz STEM i ostalih znanstvenih/umjetničkih područja.

Časopis je besplatan. Rukopisi i recenzije se ne vraćaju i ne honoriraju.

Umnožavanje (reproduciranje), stavljanje u promet (distribuiranje), priopćavanje javnosti, stavljanje na raspolaganje javnosti odnosno prerada u bilo kojem obliku nije dopuštena bez pismenog dopuštenja Nakladnika. Sadržaj objavljen u Glasilu Future može se slobodno koristiti u osobne i obrazovne svrhe uz obvezno navođenje izvora. 


\section{Glasilo Future}

\section{Stručno-znanstveni časopis}

FUTURA - stručno-znanstvena udruga za promicanje održivog razvoja, kulture i međunarodne suradnje, Bana Josipa Jelačića 13 a, 22000 Šibenik, Hrvatska

(2018) $1(5-6) 01-52$

\section{SADRŽAJ:}

\section{Izvorni znanstveni rad (original scientific paper)}

Str.

B. Dorbić, Lea Zemunović, Tea Zemunović, Emilija Friganović, Elma Temim, Katica Arar

Istraživanje općih saznanja o nekim vrstama trajnica na Mediteranu

A research on common knowledge about some perennial species in the Mediterranean region

Branka Stipanović

Stavovi maslinara o podizanju konkurentnosti maslinarstva u Dalmaciji u kontekstu ARISTOIL projekta

Attitudes of olive growers in Dalmatia region about competiveness growth in context of ARISTOIL project

\section{Stručni rad (professional paper)}

\section{Blažević}

Ogled o urbanim i prirodnim vrijednosnicama Šibenika u kontekstu turističke perspektive

An overview of urban and natural values of Šibenik in the context and from tourism perspective

J. E. Meeker, Z. Lišnić, B. Dorbić, Emilija Friganović, Ž. Španjol, Zvezda Bogevska Mogućnosti uporabe nekih jestivih submediteranskih autohtonih i alohtonih vrsta za održive dekorativne vrtove na kršu

Opportunities for use of some edible sub-Mediterranean autochthonous and allochthonous species for sustainable ornamental gardens in karst landscapes

\section{Nekategorizirani rad (uncategorised paper)}

\section{Zdenka Bilušić}

Vijesti

News 


\title{
Stavovi maslinara o podizanju konkurentnosti maslinarstva u Dalmaciji u kontekstu ARISTOIL projekta
}

\section{Attitudes of olive growers in Dalmatia region about competiveness growth in context of ARISTOIL project}

\author{
Branka Stipanović $^{*}$
}

izvorni znanstveni rad (original scientific paper)

doi: $10.32779 /$ gf.1.5-6.2

\section{Sažetak}

$\mathrm{U}$ istraživanju je analizirana uloga ARISTOIL projekta u podizanju konkurentnosti maslinarstva $\mathrm{u}$ dalmatinskim županijama te su analizirani stavovi maslinara o ciljevima projekta ARISTOIL. Također je istraženo jesu li stavovi maslinara o ciljevima ARISTOIL projekta uvjetovani sociodemografskim profilom; konkretno dobnom i obrazovnom strukturom te lokacijom (županijom) u kojoj posluju. U istraživanju su korišteni sekundarni i primarni podatci. Rezultati istraživanja pokazuju da je proces informiranja i educiranja maslinara o provedbi ARISTOIL projekta nužno prilagoditi postojećoj obrazovnoj strukturi da bi se optimizirala provedba ciljeva projekta.

Ključne riječi: poljoprivreda, maslinarstvo, ARISTOIL.

\begin{abstract}
The research analyzes the attitudes of olive oil producers towards the role of the ARISTOIL project in raising the competitiveness of olive growing in the Dalmatian counties. It has also been investigated whether the attitude of the olive oil producers about the objectives of the ARISTOIL project is conditioned by the sociodemographic profile; specifically, the age, educational structure and the location (County) in which they operate. The study used secondary and primary data. Research results show that the process of informing and educating the olive oil producers on the implementation of the ARISTOIL project needs to be adapted to the existing educational structure in order to optimize the implementation of the project objectives.
\end{abstract}

\footnotetext{
${ }^{1}$ OPG Žaja\&Stipanović, Žaje 35, 21228 Vinovac, Republika Hrvatska.

* Dr. sc. Branka Stipanović, pred., e-mail: brankastipanovic7@gmail.com.
} 
Keywords: agriculture, olive growing, ARISTOIL.

\section{Uvod}

U istraživanju je predstavljena uloga projekta ARISTOIL u podizanju razine konkurentnosti maslinarstva u mediteranskoj regiji. Kako hrvatske regije Dalmacija i Istra imaju značajne komparativne prednosti i dugu tradiciju u maslinarstvu, ključno je stvoriti optimalne preduvjete za uključivanje hrvatskih maslinara u navedeni projekt (Žanetić, 2012; Bilušić, 2017).

Cilj istraživanja je analizirati stavove maslinara iz četiri dalmatinske županije o ciljevima projekta ARISTOIL. Iz općeg cilja proizlazi i specifični cilj, a to je utvrditi postoji li statistički značajna veza između stavova maslinara o provedbi projekta ARISTOIL i sociodemografskog profila maslinara.

U radu se polazi od sljedećih hipoteza:

- H1 - stav maslinara o ciljevima projekta ARISTOIL nije uvjetovan dobnom strukturom ispitanika,

- H2 - stav maslinara o ciljevima projekta ARISTOIL nije uvjetovan obrazovnom strukturom ispitanika,

- H3 - stav maslinara o ciljevima projekta ARISTOIL nije uvjetovan županijskim središtem u kojem posluje OPG ispitanika,

- H4 - sociodemografska segmentacija i ciljno usmjeren pristup educiranju i informiranju pojedinih skupinama maslinara ključan je preduvjet motivacije za uključenje u projekt ARISTOIL.

Prilikom provedbe istraživanja korištena je kombinacija sekundarnih i primarnih podataka. Temeljni izvori sekundarnih podataka u istraživanju su bili znanstveni i stručni članci o odabranom predmetu istraživanja, a kao instrument za provedbu primarnog istraživanja stavova maslinara o ciljevima projekta ARISTOIL je korišten strukturirani anketni upitnik. Korištene su znanstveno-istraživačke metode indukcije, dedukcije, sinteze, analize i deskripcije. Za obradu primarnih podataka je korištena deskriptivna statistika, a za istraživanje značajnosti statističke veze između stava maslinara i sociodemografskih značajki korišten je Hi-kvadrat test.

Rad je podijeljen na ukupno šest poglavlja. U uvodnom poglavlju predstavljani su predmet i ciljevi istraživanja, hipoteze istraživanja te metodologija i struktura rada. Drugo poglavlje je teorijski okvir istraživanja $\mathrm{u}$ kojem se navodi osvrt na značajke projekta ARISTOIL na temelju konzultiranja rezultata dosadašnjih istraživanja na tu temu. Metodološki podatci o ciljanoj populaciji, veličini i načinu odabira uzorka istraživanja, načinu provedbe istraživanja i instrumentu prikupljanja primarnih podataka navedeni su u trećem poglavlju rada, a u narednom poglavlju su predstavljeni i interpretirani 
rezultati istraživanja. Na temelju postavljenih hipoteza i rezultata istraživanja, u poglavlju rasprava je proveden proces verifikacije hipoteza. Posljednje poglavlje je zaključak istraživanja.

\section{Materijali i metode}

Ciljanu populaciju u istraživanju činili su maslinari, vlasnici obiteljskih poljoprivrednih gospodarstva s područja četiriju dalmatinskih županija; Zadarske, Šibensko-kninske, Splitsko-dalmatinske i Dubrovačko-neretvanske županije. Iz ukupne ciljane populacije je metodom namjernog uzorkovanja (kvotnog uzorka) odabrano po 40 maslinara iz svake od odabranih županija. Ukupna planirana veličina uzorka iznosila je $\mathrm{N}=160$ ispitanika. Istraživanje je provedeno putem online upitnika tijekom svibnja 2018. godine. Prikupljeni su odgovori od ukupno $n=118$ ispitanika, od čega je po 30 ispitanika iz Zadarske i Šibensko-kninske županije te po 29 ispitanika iz Splitsko-dalmatinske i Dubrovačkoneretvanske županije.

Instrument za prikupljanje primarnih podataka istraživanja bio je strukturirani upitnik sastavljen od ukupno devet pitanja zatvorenog tipa. Prva tri pitanja odnosila su se na demografsku strukturu ispitanika, a ostala pitanja na ispitivanje stavova o ciljevima projekta ARISTOIL. Za mjerenje stavova ispitanika o pojedinim ciljevima navedenog projekta korištena je Likertova skala od 1 do 5.

Ispitanici su podijeljeni na ukupno četiri razreda s obzirom na kriterij dobne strukture. Prvi dobni razred činili su ispitanici od 25 do 35 godina, drugi dobni razred ispitanici od 36 do 40 godina, treći ispitanici od 46 do 55 godina, a u četvrti drugi razred uključeni su ispitanici s više od 55 godina. Podatci o dobnoj strukturi ispitanika prikazani su na grafikonu (Slika 1.).

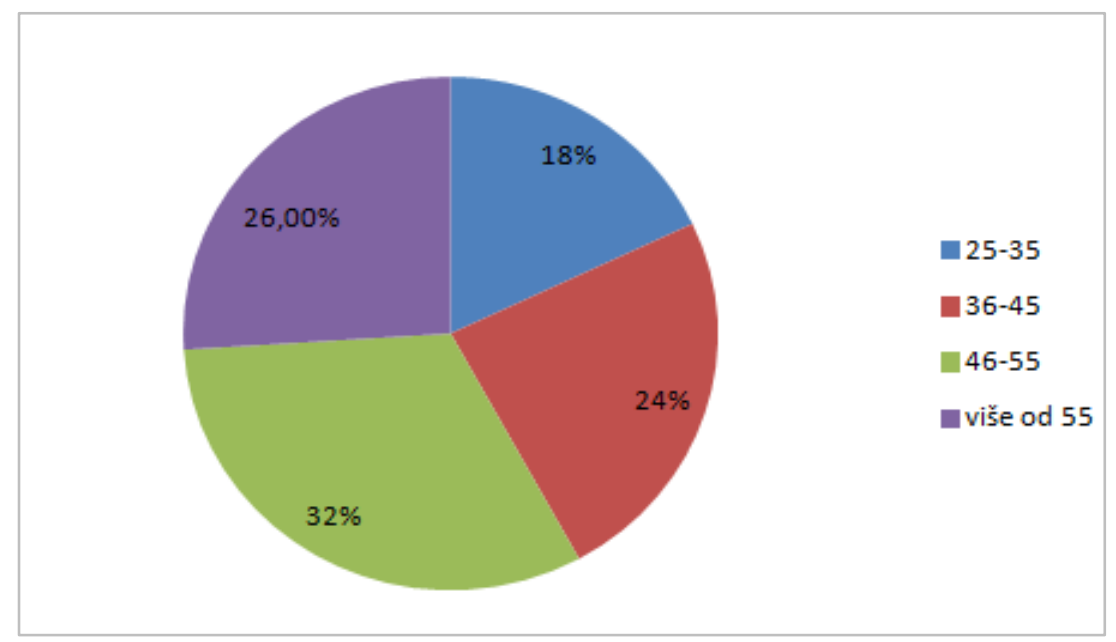

Slika 1. Grafikon: podatci o dobnoj strukturi ispitanika.

Figure 1. Chart: Age structure of respondents. 
Podatci u grafikonu (Slika 1.) pokazuju da je u dobnoj strukturi ispitanika prevladavao razred od 46 do 55 godina s udjelom od $32 \% .26 \%$ udjela u uzorku su činili ispitanici u dobnoj skupini s više od 55 godina. Mlađe dobne skupine od 25 do 35 i od 36 do 45 godina bile su manje zastupljene u dobnoj strukturi ispitanika. Udio skupine od 25 do 35 godina iznosio je $18 \%$, a udio skupine od 36 do 45 godina $24 \%$.

Drugi kriterij na temelju kojeg je prikazan sociodemografski profil ispitanika je obrazovna struktura. Ispitanici su klasificirani u skupine bez stručne spreme, sa srednjom stručnom spremom, s višom (do 3 godine visokoškolskog obrazovanja) i visokom stručnom spremom (do 5 godina visokoškolskog obrazovanja) te u skupinu ostali (magisterij, doktorat). Podatci o obrazovnoj strukturi ispitanika prikazani su u grafikonu (Slika 2.).

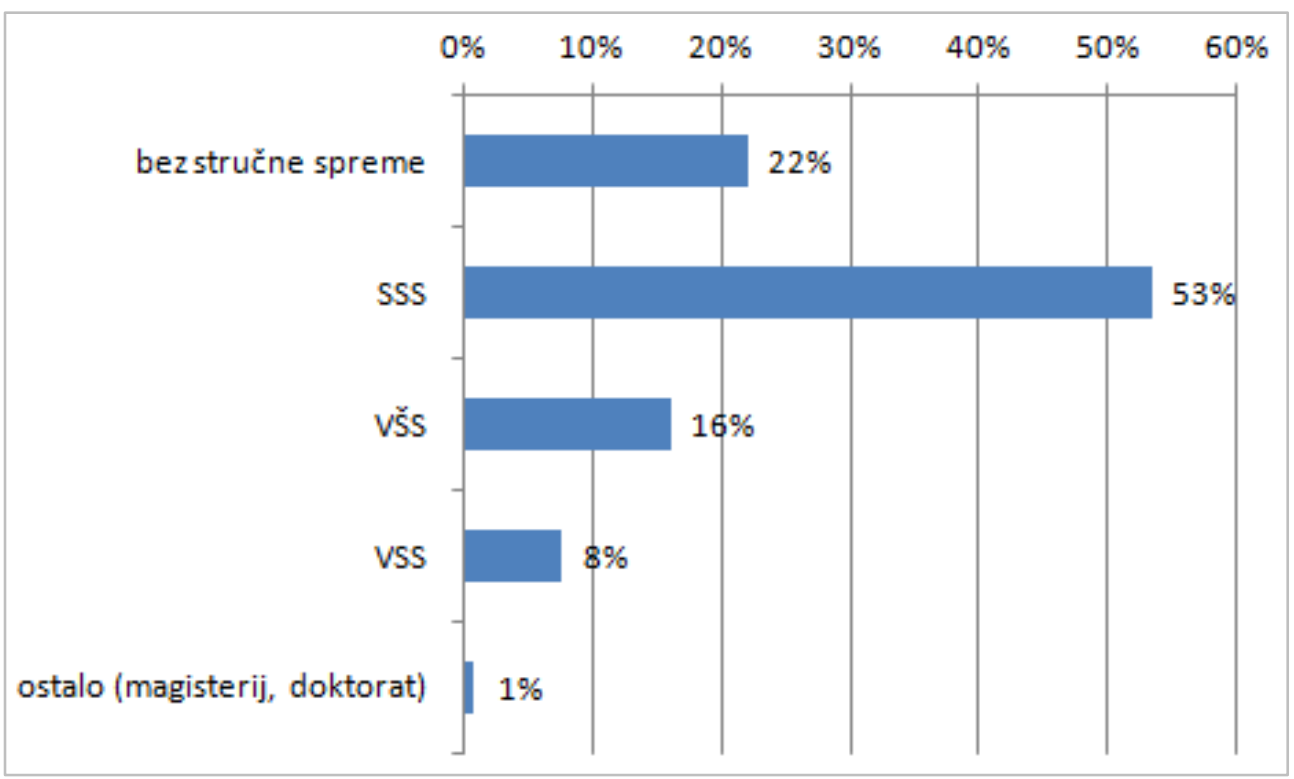

Slika 2. Grafikon: obrazovna struktura ispitanika.

Figure 2. Chart: educational structure of respondents.

Podatci u grafikonu (Slika 2.) pokazuju da su u ukupnoj obrazovnoj strukturi ispitanika prevladavali ispitanici sa srednjom stručnom spremom s udjelom od $53 \%$. Druga po učestalosti obrazovna skupina je bila bez stručne spreme s udjelom od $22 \%$, a ispitanici s VŠS i VSS spremom su zajedno sačinjavali $24 \%$ udjela. U ostalu skupinu ispitanika (magisterij, doktorat) ubrajao se $1 \%$ ispitanika.

Udio ispitanika iz pojedinih dalmatinskih županija u istraživanju prikazan je grafikonom (Slika 3.). 


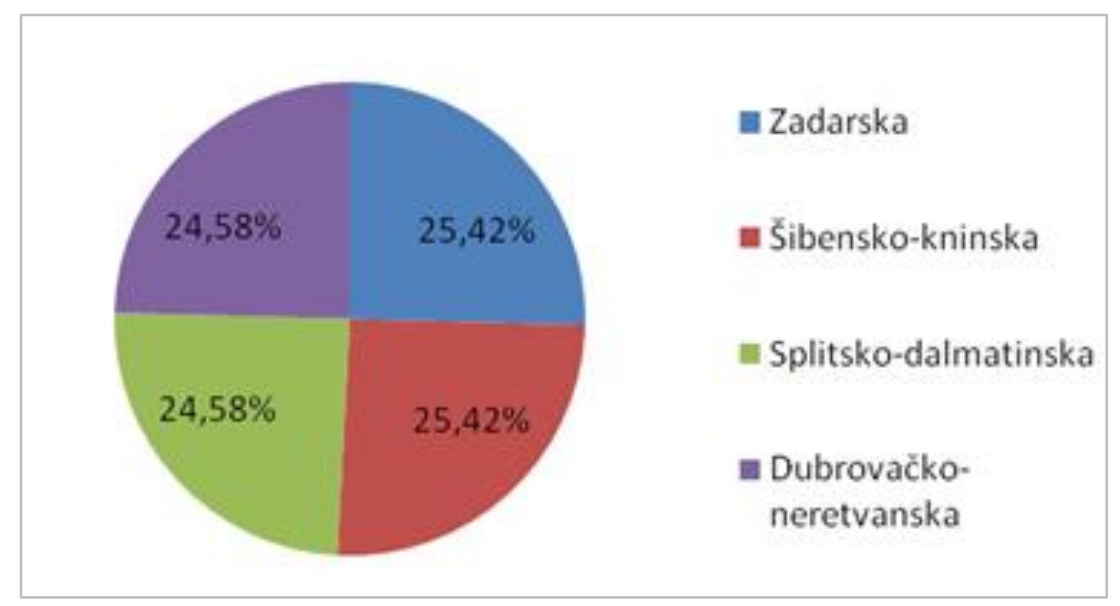

Slika 3. Grafikon: udio ispitanika iz pojedinih dalmatinskih županija.

Figure 3. Chart: volume of respondents from selected Dalmatian Counties.

Podatci u grafikonu (Slika 3.) ukazuju na ravnomjernu distribuciju ispitanika po županijama što je rezultat namjernog (kvotnog) uzorkovanja ciljne populacije.

\section{Teorijski okvir istraživanja}

U teorijskom okviru istraživanja predstavljena je uloga projekta ARISTOIL u podizanju razine konkurentnosti maslinarskog sektora mediteranske regije na globalnoj razini.

Maslinarstvo je na razini Europske unije prepoznato kao poljoprivredna grana sa značajnim potencijalima razvoja na globalnoj razini. S ciljem poticanja razine konkurentnosti maslinarstva pokrenut je projekt ARISTOIL čijom se realizacijom teži osigurati razvoj i primjenu inovativnih rješenja i standardizirane metodologije kontrole kvalitete finalnog proizvoda u maslinarstvu (CamponCerro et al., 2018). Putem navedenog projekta se sredstva iz Europskog fonda za regionalni razvoj alociraju u mediteranske zemlje koje imaju značajne komparativne prednosti u procesu proizvodnje maslinova ulja. Provedbom projekta se želi unaprijediti tehnološka osnovica proizvodnje i kvaliteta maslinova ulja s nutricionističkog i zdravstvenog stajališta, pri čemu se osobita pozornost posvećuje ukupnom sadržaju i sastavu fenola u maslinovu ulju (Žanetić et al., 2012; Evangelia et al., 2012).

$\mathrm{Na}$ razini Europske unije se ujedno osniva neprofitna savjetodavna organizacija Svjetski centar maslinova ulja u funkciji zdravlja (engl. World Olive Center for Health) čija je zadaća kontinuiranim ulaganjem u istraživanje i razvoj podizati razinu konkurentnosti maslinova ulja mediteranske regije. U radu navedene organizacije sudjeluje multidisciplinarni tim europskih i američkih znanstvenika. U realizaciji projekta partnersku ulogu imaju Sveučilište u Splitu, Institut za jadranske kulture i melioraciju krša te Udruga maslinara iz Vele Luke. Koordinator projekta je Grčka s naglaskom na ulogu Sveučilišta u Ateni. Osim ulaganja u unaprjeđenje tehnološke osnovice proizvodnje maslinova ulja, centar ima ulogu u osiguranju savjetodavne podrške u razvoju marketinške orijentacije maslinara 
te $\mathrm{u}$ promicanju zaštite proizvoda oznakom geografskog porijekla kao diferencijskim alatom na suvremenom tržištu (Benincasa et al., 2017). Mediteranska regija ima superiorne komparativne prednosti u proizvodnji maslinova ulja na globalnoj razini te je najveći izvoznik maslinova ulja na globalnoj razini s udjelom izvoza od ukupno $95 \%$, a tržišnu prepoznatljivost su osobito stekle Grčka, talijanske regije Sicilija i Kalabrija te Andaluzija u Španjolskoj (Krimnianioti, 2016). S obzirom na pedološke i klimatske značajke hrvatskih regija Dalmacije i Istre (Franić i Grgić, 2002), postoji značajan potencijal za stvaranje globalne tržišne prepoznatljivosti maslinova ulja iz navedenih regija na globalnoj razini, a koordinatorica projekta za RH prof. dr. sc. Tea Bilušić (2017) ističe da Hrvatska ima sorte s kojima dobiva na vrijednosti.

Temeljni ciljevi koji se planiraju ostvariti na temelju projekta ARISTOIL jesu (Krimnianioti, 2016):

1. podizanje razine inovativne proizvodnje maslinova ulja $\mathrm{u}$ mediteranskim zemljama $\mathrm{s}$ naglaskom na uvođenje metodologije kontrole kvalitete koja dovodi do unaprjeđenja nutricionističkih značajki ulja i povećanja dobrobiti na ljudsko zdravlje putem udjela i sastava fenola. Na taj se način doprinosi standardizaciji kvalitete maslinova ulja u mediteranskoj regiji;

2. implementacija projekta ARISTOIL ujedno podrazumijeva ulaganja u edukaciju 3230 proizvođača i prerađivača maslinova ulja putem seminara i radionica, a za prerađivače se planira osigurati kontinuirana savjetodavna podrška u projektu implementacije inovativne tehnologija proizvodnje;

3. podizanje razine svijesti i znanja krajnjih kupaca o značajkama maslinova ulja kao nutricionistički i zdravstveno visokovrijednog proizvoda je također jedan od ciljeva provedba projekta ARISTOIL. Sukladno europskoj regulativi EU 432/2012, potrošači imaju pravo na informiranje o zdravstvenim dobrobitima maslinova ulja na temelju uvida u sadržaj fenola u proizvodu kojeg kupuju. Važna informacija za krajnje potrošače je da se djelotvoran učinak maslinova ulja postiže pri dnevnoj konzumaciji od $20 \mathrm{~g}$, a ulje treba sadržavati minimalno 5 mg fenolnog spoja hidroksitirozola;

4. standardizacija i normizacija postaje značajan čimbenik u osiguranju konkurentske prednosti na globalnom tržištu. Stoga se u okviru projekta ARISTOIL planira razviti proces certifikacije maslinara oznakom "Health Claim" kojom se osigurava zdravstvena dobrobit certificiranog ulja na temelju sukladnosti kemijskog sastava maslinova ulja s minimalnom razinom fenolnih spojeva. Proces razvoja standarda povjerava se u certifikacijskim centrima u Španjolskoj i Grčkoj čiji su kapaciteti dostatni za zadovoljavanje certifikacijskih potreba na razini cijele mediteranske regije;

5. razvoj udruženja ili klastera mediteranskih proizvođača maslinova ulja cilj je projekta ARISTOIL kojem se teži unaprijediti kooperacija i umrežavanje svih sudionika u lancu vrijednosti u maslinarstvu na razini Mediterana. Važnu ulogu u povezivanju i umrežavanju 
sudionika klastera ima i razvoj elektroničke platforme (e-hub) kojom se omogućava komunikacija i razmjena iskustava i dobrih praksi. Navedena platforma ujedno je osnova za dugoročno cjeloživotno usavršavanje maslinara putem pružanja informacija o novim tržišnim mogućnostima, seminarima, izložbama i inovativnim idejama na sektorskoj razini.

Planirani terminski plan za realizaciju projekta je tri godine, u razdoblju od 2016. - 2019. godine (Bilušić, 2017).

\section{Rezultati istraživanja}

Poglavlje o rezultatima istraživanja strukturirano je u dvije podcjeline. U prvoj su predstavljeni stavovi ispitanika o ciljevima projekta ARISTOIL, a u drugoj podcjelini su na temelju hi-kvadrat testa ispitane postavljene nulte hipoteze o statističkoj značajnosti veza između sociodemografskih značajki ispitanika kao nezavisnih varijabli i stavova o ciljevima ARISTOIL projekta kao zavisne varijable u istraživanju.

\section{Rezultati istraživanja - stavovi ispitanika o pojedinim ciljevima projekta ARISTOIL}

Stav ispitanika o inovativnosti proizvodnje kao jednom od temeljnih ciljeva projekta ARISTOIL prikazan je Tablicom 1. na temelju aritmetičke sredine ili prosječne ocjene stava o važnosti inovacija u proizvodnji maslinova ulja. Ispitanici su iskazali stav na Likertovoj skali od 1 do 5 gdje je 1 - potpuno nevažno, a 5 - izuzetno važno.

Tablica 1. Stav ispitanika o važnosti inoviranja proizvodnje maslinova ulja.

Table 1. Respondents' attitudes towards importance of olive oil production innovation.

\begin{tabular}{|l|l|l|}
\hline Ocjena (x) & Frekvencija (f) & F(x) \\
\hline 1 - potpuno nevažno & 5 & 5 \\
\hline $2-$ nevažno & 5 & 10 \\
\hline $3-$ ni važno ni nevažno & 5 & 15 \\
\hline $4-$ važno & 28 & 112 \\
\hline $5-$ vrlo važno & 75 & 375 \\
\hline UKUPNO & 118 & 517 \\
\hline Prosječna ocjena (F(x)/f) & & $\mathbf{4 , 3 8}$ \\
\hline
\end{tabular}

Prosječna ocjena stava ispitanika o važnosti inoviranja proizvodne tehnologije u maslinarstvu pokazuje da ispitanici ocjenjuju proizvodne inovacije važnima, što su iskazali prosječnom ocjenom od 
4,38. U istraživanju je ispitana i upoznatost ispitanika s novim tehnologijama određivanja fenolnih komponenti u maslinovom ulju, konkretno s NMR tehnologijom. $36 \%$ ispitanika izjavilo je da su informirani o značajkama navedene tehnologije.

Stav ispitanika o edukaciji i usavršavanju kao jednom od temeljnih ciljeva projekta ARISTOIL prikazan je Tablicom 2. na temelju aritmetičke sredine ili prosječne ocjene stava o važnosti kontinuiranog ulaganja u edukaciju u proizvodnji maslinova ulja. Ispitanici su iskazali stav na Likertovoj skali od 1 do 5 gdje je 1 - potpuno nevažno, a 5 - izuzetno važno.

Tablica 2. Stav ispitanika o važnosti edukacije u procesu proizvodnje maslinova ulja.

Table 2. Respondents' attitudes towards importance of education in olive oil production process.

\begin{tabular}{|l|l|l|}
\hline Ocjena $(\mathbf{x})$ & Frekvencija (f) & $\mathbf{F ( x )}$ \\
\hline 1 - potpuno nevažno & 6 & 5 \\
\hline 2 - nevažno & 5 & 10 \\
\hline 3 - ni važno ni nevažno & 12 & 36 \\
\hline 4 - važno & 33 & 132 \\
\hline 5 - vrlo važno & 62 & 310 \\
\hline UKUPNO & 118 & 493 \\
\hline Prosječna ocjena $(\mathbf{F}(\mathbf{x}) / \mathbf{f})$ & & $\mathbf{4 , 1 8}$ \\
\hline
\end{tabular}

Prosječna ocjena stava ispitanika o važnosti edukacije u maslinarstvu (Tablica 2.) pokazuje da ispitanici ocjenjuju edukaciju važnim čimbenikom u poslovanju, što su iskazali prosječnom ocjenom od 4,18 .

Stav ispitanika o standardizaciji proizvodnje (utvrđivanju minimalne razine standarda kvalitete maslinova ulja u mediteranskoj regiji) kao jednom od temeljnih ciljeva projekta ARISTOIL prikazan je Tablicom 3. na temelju aritmetičke sredine ili prosječne ocjene stava o važnosti standardizacije kvalitete maslinova ulja. Ispitanici su iskazali stav na Likertovoj skali od 1 do 5 gdje je 1 - potpuno nevažno, a 5 - izuzetno važno. Prosječna ocjena stava ispitanika o važnosti standardizacije u maslinarstvu pokazuje da ispitanici ocjenjuju standardizaciju nevažnim čimbenikom u konkurentnom poslovanju, što su iskazali prosječnom ocjenom od 2,26.

Stav ispitanika o važnosti umrežavanja i komunikacije putem e-hub platforme iskazan je u Tablici 4. Ispitanici su iskazali stav na Likertovoj skali od 1 do 5 gdje je 1 - potpuno nevažno, a 5 - izuzetno važno. Prosječna ocjena stava ispitanika o važnosti umrežavanja i komunikacije putem elektroničke 
platforme u maslinarstvu pokazuje da ispitanici ocjenjuju umrežavanje ni nevažnim ni važnim čimbenikom u konkurentnom poslovanju, što su iskazali prosječnom ocjenom od 3,03.

Tablica 3. Stav ispitanika o važnosti standardizacije u procesu proizvodnje maslinova ulja.

Table 3. Respondents' attitudes towards importance of standardization in olive oil production process.

\begin{tabular}{|l|l|l|}
\hline Ocjena (x) & Frekvencija (f) & F(x) \\
\hline 1 - potpuno nevažno & 22 & 5 \\
\hline 2- nevažno & 28 & 10 \\
\hline 3 - ni važno ni nevažno & 32 & 96 \\
\hline 4 - važno & 24 & 96 \\
\hline 5 - vrlo važno & 12 & 60 \\
\hline UKUPNO & 118 & 267 \\
\hline Prosječna ocjena (F(x)/f) & & $\mathbf{2 , 2 6}$ \\
\hline
\end{tabular}

Tablica 4. Stav ispitanika o važnosti umrežavanja i komunikacije putem e-hub platforme u procesu proizvodnje maslinova ulja.

Table 4. Respondents' attitudes towards importance of networking and e-hub communication platform in olive oil production process.

\begin{tabular}{|l|l|l|}
\hline Ocjena (x) & Frekvencija (f) & F(x) \\
\hline 1 - potpuno nevažno & 18 & 5 \\
\hline $2-$ nevažno & 22 & 10 \\
\hline $3-$ ni važno ni nevažno & 11 & 33 \\
\hline $4-$ važno & 25 & 100 \\
\hline $5-$ vrlo važno & 42 & 210 \\
\hline UKUPNO & 118 & 358 \\
\hline Prosječna ocjena (F(x)/f) & & $\mathbf{3 , 0 3}$ \\
\hline
\end{tabular}

$\mathrm{Na}$ temelju skupa ocjena pojedinih ciljeva ispitanika o ARISTOIL projektu generirana je prosječna ocjena stava ispitanika o provedbi projekta kao cjelini (Tablica 5.). 
Tablica 5. Stav ispitanika o provedbi ARISTOIL projekta u cjelini.

Table 5. Respondents' attitude about ARISTOIL project implementation in general.

\begin{tabular}{|l|r|}
\hline $\begin{array}{l}\text { Stav o pojedinom cilju } \\
\text { projekta }\end{array}$ & Ocjena \\
\hline Inovacije & 4,38 \\
\hline Edukacija & 4,18 \\
\hline Standardizacija & 2,26 \\
\hline Umrežavanje i e-hub platforma & 3,03 \\
\hline Prosječna ocjena & $\mathbf{3 , 5 0}$ \\
\hline
\end{tabular}

Rezultati istraživanja pokazuju da ispitanici ocjenjuju provedbu ciljeva ARISTOIL projekta važnom u podizanju razine konkurentnosti u maslinarstvu na razini mediteranske regije. Ovu ocjenu potvrđuje i distribucija frekvencija u posljednjem pitanju vezanom za stav o projektu kao cjelini (Tablica 6.).

Tablica 6. Stav ispitanika o provedbi ARISTOIL projekta kao cjelini.

Table 6. Respondents' attitude about ARISTOIL project implementation in general.

\begin{tabular}{|c|c|c|}
\hline Ocjena $(x)$ & Frekvencija (f) & $\mathbf{F}(\mathbf{x})$ \\
\hline 1 - potpuno nevažno & 13 & 13 \\
\hline 2 -nevažno & 14 & 28 \\
\hline 3 - ni važno ni nevažno & 24 & 72 \\
\hline 4 - važno & 36 & 144 \\
\hline 5 - vrlo važno & 31 & 155 \\
\hline UKUPNO & 118 & 412 \\
\hline $\begin{array}{l}\text { Prosječna } \\
(\mathbf{F}(\mathbf{x}) / \mathbf{f})\end{array}$ & & $\mathbf{3 , 5 0}$ \\
\hline
\end{tabular}

Stav ispitanika o realizaciji projekta ARISTOIL u cjelini ukazuje na to da ispitanici smatraju provedbu projekta važnom za podizanje konkurentnosti u maslinarstvu.

Ispitivanje statističke značajnosti između sociodemografskih značajki ispitanika i stava o ciljevima ARISTOIL projekta

U Tablici 7. je ispitano postoji li statistički značajna veza između sociodemografske značajke dobi ispitanika i stava ispitanika o ukupnim ciljevima ARISTOIL projekta. 
Tablica 7. Hi-kvadrat test - ispitivanje statističke značajnosti odnosa između dobi i stavova ispitanika o ARISTOIL projektu.

Table 7. Chi-square test - statistical significance between age and respondents' attitude towards ARISTOIL project.

\begin{tabular}{|l|l|r|r|r|}
\hline promatrane frekvencije & \multicolumn{1}{|l|}{$\mathbf{1 - 3}^{\mathbf{2}}$} & $\mathbf{4}$ & $\mathbf{5}$ & UKUPNO \\
\hline $25-35$ & 8 & 9 & 4 & 21 \\
\hline $36-45$ & 13 & 9 & 6 & 28 \\
\hline $46-55$ & 15 & 8 & 15 & 38 \\
\hline više od 55 & 15 & 10 & 6 & 31 \\
\hline UKUPNO & $\mathbf{5 1}$ & $\mathbf{3 6}$ & $\mathbf{3 1}$ & $\mathbf{1 1 8}$ \\
\hline očekivane frekvencije & $\mathbf{1 - 3}$ & $\mathbf{4}$ & $\mathbf{5}$ & UKUPNO \\
\hline $25-35$ & 9,076271 & 6,40678 & 5,516949 & 21 \\
\hline $36-45$ & 12,10169 & 8,542373 & 7,355932 & 28 \\
\hline $46-55$ & 16,42373 & 11,59322 & 9,983051 & 38 \\
\hline više od 55 & 13,39831 & 9,457627 & 8,144068 & 31 \\
\hline UKUPNO & $\mathbf{5 1}$ & $\mathbf{3 6}$ & $\mathbf{3 1}$ & $\mathbf{1 1 8}$ \\
\hline
\end{tabular}

\begin{tabular}{|c|c|c|c|c|}
\hline f0 & $\mathbf{F t}$ & fo-ft & $(f 0-f t) 2$ & $(\mathbf{f 0}-\mathbf{f t}) 2 / \mathrm{ft}$ \\
\hline 8 & 9,076271 & $-1,07627$ & 1,15836 & 0,13 \\
\hline 9 & 6,40678 & 2,59322 & 6,724792 & 1,05 \\
\hline 4 & 5,516949 & $-1,51695$ & 2,301135 & 0,42 \\
\hline 13 & 12,10169 & 0,898305 & 0,806952 & 0,07 \\
\hline 9 & 8,542373 & 0,457627 & 0,209423 & 0,02 \\
\hline 6 & 7,355932 & $-1,35593$ & 1,838552 & 0,25 \\
\hline 15 & 16,42373 & $-1,42373$ & 2,027004 & 0,12 \\
\hline 8 & 11,59322 & $-3,59322$ & 12,91123 & 1,11 \\
\hline 15 & 9,983051 & 5,016949 & 25,16978 & 2,52 \\
\hline 15 & 13,39831 & 1,601695 & 2,565427 & 0,19 \\
\hline 10 & 9,457627 & 0,542373 & 0,294168 & 0,03 \\
\hline 6 & 8,144068 & $-2,14407$ & 4,597027 & 0,56 \\
\hline Ukupno & & & & 6,48 \\
\hline broj stupnjeva slobode & 6 & & & \\
\hline Postotak & $5 \%$ & & & \\
\hline hi kvadrat granični & 12,592 & & & \\
\hline
\end{tabular}

S obzirom da je testiranjem hipoteza dobiveni empirijski hi-kvadrat od 6,48 manji od teorijskog hi-kvadrata uz 6 stupnja slobode (df) i $5 \%$ signifikantnosti koji iznosi 12,592, prihvaća se nulta hipoteza da dob ispitanika nije značajna varijabla u formiranju stavu o provedbi ARISTOIL projekta.

U Tablici 8. je ispitano postoji li statistički značajna veza između sociodemografske značajke obrazovne strukture ispitanika i stava ispitanika o ukupnim ciljevima ARISTOIL projekta.

\footnotetext{
${ }^{2}$ Ocjene od 1 do 3 su spojene u isti razred da bi se izbjegla frekvencija manja od 5.
} 
Tablica 8. Hi-kvadrat test - ispitivanje statističke značajnosti odnosa između obrazovne strukture i stavova ispitanika o ARISTOIL projektu.

Table 8. Chi-square test - statistical significance between educational structure and respondents' attitude towards ARISTOIL project.

\begin{tabular}{|c|c|c|c|c|}
\hline promatrane frekvencije & $1-3$ & 4 & 5 & UKUPNO \\
\hline bez spreme & 12 & 8 & 6 & 26 \\
\hline SSS & 34 & 15 & 14 & 63 \\
\hline VŠS i VSS ${ }^{3}$ & 5 & 13 & 11 & 29 \\
\hline UKUPNO & 51 & 36 & 31 & 118 \\
\hline očekivane frekvencije & $1-3$ & 4 & 5 & UKUPNO \\
\hline bez spreme & 11,23729 & 7,932203 & 6,830508 & 26 \\
\hline SSS & 27,22881 & 19,22034 & 16,55085 & 63 \\
\hline VŠS i VSS & 12,5339 & 8,847458 & 7,618644 & 29 \\
\hline UKUPNO & 51 & 36 & 31 & 118 \\
\hline
\end{tabular}

\begin{tabular}{|lr|l|l|l|r|}
\hline f0 & \multicolumn{1}{|l|}{ Ft } & f0-ft & (f0-ft)2 & (f0-ft)2/ft \\
\hline & 12 & 11,23729 & 0,762712 & 0,581729 & 0,05 \\
\hline 8 & 7,932203 & 0,067797 & 0,004596 & 0,00 \\
\hline 6 & 6,830508 & $-0,83051$ & 0,689744 & 0,10 \\
\hline 34 & 27,22881 & 6,771186 & 45,84897 & 1,68 \\
\hline 15 & 19,22034 & $-4,22034$ & 17,81126 & 0,93 \\
\hline 14 & 16,55085 & $-2,55085$ & 6,506823 & 0,39 \\
\hline 5 & 12,5339 & $-7,5339$ & 56,75962 & 4,53 \\
\hline 13 & 8,847458 & 4,152542 & 17,24361 & 1,95 \\
\hline 11 & 7,618644 & 3,381356 & 11,43357 & 1,50 \\
\hline Ukupno & & & & $\mathbf{1 1 , 1 4}$ \\
\hline broj stupnjeva slobode & & & & \\
\hline Postotak & & $5 \%$ & & & \\
\hline hi kvadrat granični & $\mathbf{5 , 9 9 1}$ & & & \\
\hline
\end{tabular}

S obzirom da je testiranjem hipoteza dobiveni empirijski hi-kvadrat od 11,14 veći od teorijskog hi-kvadrata uz 2 stupnja slobode (df) i 5 \% signifikantnosti koji iznosi 5,991, odbija se nulta hipoteza da obrazovna struktura ispitanika nije značajna varijabla u formiranju stavu o provedbi ARISTOIL projekta.

U Tablici 9. je ispitano postoji li statistički značajna veza između sociodemografske značajke županije u kojoj ispitanik posluje i stava ispitanika o ukupnim ciljevima ARISTOIL projekta.

\footnotetext{
${ }^{3}$ Grupe VŠS, VSS i ostalo (magisterij i doktorat) su spojene da se izbjegne frekvencija manja od 5.
} 
Tablica 9. Hi-kvadrat test - ispitivanje statističke značajnosti odnosa između županijskog sjedišta i stavova ispitanika o ARISTOIL projektu.

Table 9. Chi square test - statistical significance between respondents' County and attitudes towards ARISTOIL project.

\begin{tabular}{|l|r|r|r|r|}
\hline Promatrane frekvencije & \multicolumn{1}{|c|}{} & $\mathbf{4}$ & $\mathbf{5}$ & UKUPNO \\
\hline Zadarska & 12 & 9 & 9 & $\mathbf{3 0}$ \\
\hline Šibensko-kninska & 14 & 8 & 8 & $\mathbf{3 0}$ \\
\hline Splitsko-dalmatinska & 13 & 9 & 7 & $\mathbf{2 9}$ \\
\hline Dubrovačko-neretvanska & 12 & 10 & 7 & $\mathbf{2 9}$ \\
\hline UKUPNO & $\mathbf{5 1}$ & $\mathbf{3 6}$ & $\mathbf{3 1}$ & $\mathbf{1 1 8}$ \\
\hline očekivane frekvencije & $\mathbf{1 - 3}$ & $\mathbf{4}$ & $\mathbf{5}$ & UKUPNO \\
\hline bez spreme & 12,9661 & 9,152542 & 7,881356 & $\mathbf{3 0}$ \\
\hline SSS & 12,9661 & 9,152542 & 7,881356 & $\mathbf{3 0}$ \\
\hline VŠS i VSS & 12,5339 & 8,847458 & 7,618644 & $\mathbf{2 9}$ \\
\hline Dubrovačko-neretvanska & 12,5339 & 8,847458 & 7,618644 & $\mathbf{2 9}$ \\
\hline UKUPNO & $\mathbf{5 1}$ & $\mathbf{3 6}$ & $\mathbf{3 1}$ & $\mathbf{1 1 8}$ \\
\hline
\end{tabular}

\begin{tabular}{|c|c|c|c|c|}
\hline f0 & $\mathbf{F t}$ & f0-ft & $(\mathbf{f 0}-\mathbf{f t}) 2$ & $(\mathbf{f 0}-\mathbf{f t}) 2 / \mathrm{ft}$ \\
\hline 12 & 12,9661 & $-0,9661$ & 0,933352 & 0,07 \\
\hline 9 & 9,152542 & $-0,15254$ & 0,023269 & 0,00 \\
\hline 9 & 7,881356 & 1,118644 & 1,251365 & 0,16 \\
\hline 14 & 12,9661 & 1,033898 & 1,068946 & 0,08 \\
\hline 8 & 9,152542 & $-1,15254$ & 1,328354 & 0,15 \\
\hline 8 & 7,881356 & 0,118644 & 0,014076 & 0,00 \\
\hline 13 & 12,5339 & 0,466102 & 0,217251 & 0,02 \\
\hline 9 & 8,847458 & 0,152542 & 0,023269 & 0,00 \\
\hline 7 & 7,618644 & $-0,61864$ & 0,38272 & 0,05 \\
\hline 12 & 12,5339 & $-0,5339$ & 0,285047 & 0,02 \\
\hline 10 & 8,847458 & 1,152542 & 1,328354 & 0,15 \\
\hline 7 & 7,618644 & $-0,61864$ & 0,38272 & 0,05 \\
\hline ukupno & & & & $\mathbf{0 , 7 6}$ \\
\hline broj stupnjeva slobode & 6 & & & \\
\hline postotak & $5 \%$ & & & \\
\hline hi kvadrat granični & 12,592 & & & \\
\hline
\end{tabular}

S obzirom da je testiranjem hipoteza dobiveni empirijski hi-kvadrat od 0,76 manji od teorijskog hi-kvadrata uz 6 stupnjeva slobode (df) i $5 \%$ signifikantnosti koji iznosi 12,592, prihvaća se nulta hipoteza da lokacija (županija u kojoj je sjedište) ispitanika nije značajna varijabla u formiranju stavu o provedbi ARISTOIL projekta. 


\section{Rasprava}

Rezultatima istraživanja potvrđene su nulte hipoteze o nepostojanju statistički značajne veze između dobi i županijskim sjedištem u kojem posluju maslinari, a postavljenu nultu hipotezu H2 je potrebno odbaciti jer je između stava o ciljevima ARISTOIL projekta i obrazovne strukture ispitanika dokazana statistički značajna veza. Na temelju dobivenih rezultata ujedno je moguće modificirati hipotezu H4 te zaključiti da je sociodemografska segmentacija prema obrazovnoj strukturi stanovnika i ciljano usmjeren pristup educiranju i informiranju pojedinih skupinama maslinara ključan preduvjet motivacije za uključenje u projekt ARISTOIL. S obzirom da ciljeve projekta slabije podupiru ispitanici s nižom razinom obrazovanja, upravo prema njima je važno usmjeriti proces educiranja i informiranja o dobrobitima projekta.

\section{Zaključak}

$\mathrm{Na}$ razini Europske unije se razvijaju institucionalne mjere za podizanje razine konkurentnosti mediteranske regije $\mathrm{u}$ maslinarstvu kroz pristup utemeljen na usavršavanju nutricionističkih i zdravstvenih značajki maslinova ulja. Navedene tendencije zahtijevaju inovativnu proizvodnju, ulaganja u edukaciju, provedbu procesa standardizacije i certifikacije maslinova ulja te umreženi pristup razvoju konkurentnosti utemeljen na sektorskoj suradnji. Navedene mjere implementirane su u program ARISTOIL. Uspješnost implementacije navedenog projekta ovisi o stavu i suradnji maslinara. Stav maslinara dalmatinskih županija o provedbi projekta je pozitivan, ali postoje značajne statističke razlike u stavovima o ciljevima projekta kod različitih skupina ispitanika s obzirom na kriterij obrazovne strukture te je stoga nužno ulaganje u ciljno usmjereno educiranje i informiranje maslinara kako bi ih se motiviralo na sudjelovanje u projektu.

\section{Literatura}

Benincasa, C., Lewis, J., Perri, E., Sindona, G., Tagarelli, A. (2007). Determination of trace element in Italian virgin olive oils and their characterization according to geographical origin by statistical analysis. Analytica Chimica Acta, 585(2), 366-370.

Bilušić, T. (2017). Prikupljaju se uzorci za ARISTOIL. Maslinar, 45(1), 71-74.

Campón-Cerro, A. M., Di-Clemente, E., Hernández-Mogollón, J. M., De Salvo, P., Calzati, V. (2018). Olive oil tourism in Southern Europe: Proposals for tourism development of olive grove rural areas. Revista Turismo \& Desenvolvimento, 4(21-22), 63-73.

Evangelia, K., Aggeliki, S., Eleni, M., Prokopios, M. (2012). A new concept for olive oil classification based on the oleocanthal and oleacein content through H-NMR quantitation. Planta Medica, 78(11), PJ52. 
Franić, R., Grgić, Z. (2002). Agrotourism on a Family Farm in Croatia - Prospects for Development A Case Study. Agriculturae Conspectus Scientificus, 67(3), 131-141.

Krimnianioti, M. (2016). The reinforcement of Mediterranean oil sector competitiveness (objava na društvenoj mreži). Posjećeno 06. 07. 2018. na mrežnoj stranici Linkedin: https://www.linkedin.com/pulse/reinforcement-mediterranean-olive-oil-sector-mary-krimnianioti.

Žanetić, M., Škevin, D., Vitanović, E., Špika, M. J., Perica, S. (2012). Ispitivanje fenolnih spojeva i senzorski profil dalmatinskih djevičanskih maslinovih ulja. Pomologia Croatica: Glasilo Hrvatskog agronomskog društva, 17(1-2), 19-30.

Primljeno: 06. listopada 2018. godine

Prihvaćeno: 31. prosinca 2018. godine
Received: October 06, 2018

Accepted: December 31, 2018 